\title{
TỤC NGỮ TIẾNG HÀN CÓ YẾU TỐ CHỈ CON MÈO
}

\author{
Hoàng Thị Yến* \\ Khoa Ngôn ngũu và Văn hóa Hàn Quốc, Trường Đại học Ngoại ngũu, ĐHQGHN, \\ Phạm Văn Đồng, Cầu Giấy, Hà Nội, Việt Nam \\ Nhận bài ngày 7 tháng 2 năm 2017 \\ Chỉnh sửa ngày 24 tháng 3 năm 2017; Chấp nhận đăng ngày 27 tháng 3 năm 2017 \\ Tóm tắt: Bài viết sử dụng kết hợp phương pháp miêu tả với so sánh, các thao tác khảo sát, dịch ý và \\ phân tích ngữ nghĩa, thủ pháp thống kê, phân loại; thao tác phân tích và tổng hợp để thực hiện các nhiệm vụ \\ nghiên cứu. Bài viết đã phác họa hình ảnh con mèo trong tục ngữ tiếng Hàn. Giá trị giáo huấn, truyền kinh \\ nghiệm thể hiện trong tục ngữ cho thấy một phần thế giới quan, giá trị quan, nhân sinh quan của người Hàn. \\ Tục ngữ tiếng Hàn có yếu tố chỉ con mèo cũng thể hiện thái độ phản kháng của người dân đối với những \\ bất công, cái xấu trong xã hội; nụ cười trào phúng đối với những thói hư, tật xấu của con người. Các nét \\ giống và khác trong văn hóa giữa hai dân tộc Hàn - Việt được khắc hoạ qua sự liên hệ ở những nét đặc trưng \\ tương ứng. Dấu ấn văn hóa dân tộc cũng ít nhiều được thể hiện qua tục ngữ tiếng Hàn có yếu tố chỉ mèo.
}

Từ khóa: tục ngữ tiếng Hàn, con mèo, giá trị biểu trưng, dấu ấn văn hóa

\section{Mở đầu}

Mèo có nhiều loại và thường được gọi theo các tên khác nhau dựa vào đặc điểm màu của bộ lông: mèo trắng, mèo đen, mèo mướp, mèo mun, mèo nhị thể, mèo tam thể... Trên thế giới, quan niệm về mèo ở từng quốc gia, từng thời kì là không đồng nhất, khi thì tốt, khi thì xấu. Người Việt cho rằng: Mèo đến nhà thì khó, chó đến nhà thì sang... Trong 12 con giáp, người tuổi mão được coi là rất thông minh và trung thực, nhạy cảm và có phần hơi cảnh giác ${ }^{(1)}$.

* ĐT: 84-972157070, Email: hoangyen70@gmail.com http://laodong.com.vn/the-gioi/tai-sao-trung-quocnam-tho-viet-nam-nam-meo-19765.bld, 30/12/2016 Giải thích vì sao Trung Quốc và Hàn Quốc đều gọi là năm Thỏ, nhưng ở Việt Nam lại là năm Mèo, TS. Sim Sang Joon (Giám đốc Trung tâm Giao lưu văn hoá Việt - Hàn) viết: "Con mèo tuy không phải loài vật nằm trong Thập nhị chi nhưng lại được ghi âm chữ Hán giống với con thỏ (máo - âm Hán-Việt là "miêu”). Trong tiếng
Trong tiếng Hàn, xuất hiện khá nhiều các công trình nghiên cứu về tục ngữ liên quan đến động vật, tiêu biểu như: tác giả Jang Jae Hwan (2009) tiến hành so sánh tục ngữ liên quan đến động vật trong tiếng Hàn, tiếng Nhật (trọng tâm là tục ngữ có yếu tố chỉ ngựa và chó). Tác giả Kim Myung Hwa (2011) nghiên cứu so sánh tục ngữ liên quan đến động vật, cụ thể là 12 con giáp trong tiếng Hàn và tiếng Trung... Trong tiếng Việt, gần đây có các nghiên cứu

Trung Quốc, hai từ này khác nhau về dấu, song về âm thì thỏ (măo) và mèo (máo) đều là mao. Điều thú vị nữa là trong Việt Nam tự điển, thì chữ Mão - nghĩa là con thỏ - lại được dùng để chỉ con mèo". Tác giả cho rằng, Việt Nam không có điều kiện môi trường để loài thỏ phát triển sinh sôi. Việt Nam là văn hoá thảo mộc - môi trường phong phú đa dạng các thảm thực vật đan xen lẫn nhau bởi khí hậu nóng ẩm, mưa nhiều. Có lẽ vì thế, người Việt đã biến cải cho phù hợp với môi trường sống của mình. Ông nhấn mạnh: "Việc thay đổi tinh tế chữ Máo - chỉ con thỏ - sang con mèo đã cho thấy tài trí của người Việt Nam trong tiếp biến văn hoá!" 
đối chiếu tục ngữ tiếng Hàn và tiếng Việt của Trần Văn Tiếng (2006); Nguyễn Thùy Dương (2013), Hoàng Thị Yến và Nguyễn Thùy Dương (2016)... Bài viết là một trong chuỗi các bài viết về tục ngữ liên quan đến 12 con giáp trong tiếng Hàn của chúng tôi. Kết quả khảo sát cho thấy, mèo là một trong số 164 loài vật xuất hiện trong công trình của Song Jae Seun (1997). Đây là công trình tiêu biểu, tập hợp đầy đủ nhất các đơn vị tục ngữ có yếu tố chỉ động vật trong tiếng Hàn. Trong số 3.498 đơn vị tục ngũ̃ có yếu tố chỉ động vật trong 12 con giáp, các đơn vị có yếu tố chỉ con mèo có 196 đơn vị (chiếm 5,6\%).

Chúng tôi sử dụng kết hợp phương pháp miêu tả với so sánh - đối chiếu (ở mức độ liên hệ với tiếng Việt) để làm rõ đặc điểm ngũ̃ nghĩa của các đơn vị tục ngữ tiếng Hàn có yếu tố chỉ con mèo. Các thao tác khảo sát; thống kê, phân loại; dịch và phân tích ngữ nghĩa kết hợp phân tích thành tố văn hóa; thực hiện hệ thống, tổng hợp thành các phạm trù ngữ nghĩa biểu trưng... được áp dụng nhằm giải quyết 3 nhiệm vụ nghiên cứu sau: i) Khắc họa hình ảnh con mèo trong tục ngữ tiếng Hàn; ii) Phân tích ý nghĩa biểu trưng của các đơn vị tục ngữ tiếng Hàn có yếu tố chỉ con mèo; các nét văn hóa tương đồng và khác biệt trong văn hóa Hàn - Việt được phác họa qua thao tác liên hệ (nguồn ngữ liệu tiếng Việt trong Nguyễn Văn Nở (2008), Vũ Ngọc Phan (2008)...); iii) Phân tích dấu ấn văn hóa dân tộc Hàn qua tục ngữ tiếng Hàn có yếu tố chỉ mèo.

\section{Hình ảnh mèo trong tục ngữ tiếng Hàn}

\section{1. Đặc điểm hình thức và tập tính của mèo} trong tuc ngũ

Mèo là loài động vật có hình dáng giống hổ, vì thế, thường được người Việt gọi là "tiểu hổ". Người Việt mô phỏng tiếng mèo kêu bằng từ tượng thanh meo meo trong khi người Hàn lại dùng từ 아옹 $a$-ong (hơi giống khi ta phát âm tiếng $a o \ldots$ hay ngao.... Người Hàn có câu: 고양이 뿔 외에는 다 있다 bộ phận nào mèo cũng có, chỉ không có sùng. Các bộ phận cơ thể của mèo xuất hiện trong tục ngữ có: mặt mèo 고양이 상/ 낮짝, ria mèo trắng 흰 수염, trán hẹp 좁은 이마, vuốt 발톱, mèo không có sừng 뿔, cổ mèo 고양이 목, gan bàn chân mèo 고양이 발바닥, mèo giống hổ 범 $=$ tiểu hổ, 고양이 불알 hòn dái mèo, tay mèo 고양이 손, lông 털 ...

Theo các tiêu chí khác nhau, ta thấy có khá nhiều loại/ loài mèo xuất hiện trong tục ngữ tiếng Hàn: mèo đen 검은 고양이; mèo mù 눈 먼 고양이; mèo già 늙은 고양이 - mèo con 고양이 새끼; mèo nhát겁 많은 고양이 ; mèo đực 수코양이 - mèo cái 암코양이, mèo đói 굶주린 고양이 - mèo no bụng 배부른 고양이, mèo gầy 마른 고양이, mèo sống 산 고양이- mèo chết 죽은 고양이...

Thức ăn yêu thích của mèo khá đa dạng, có thể kể đến: chuột 쥐, mỡ 기름종지, thịt cá 고기... Mèo không ăn được vỏ cua 게껍질, sò 고막... Mèo ăn cơm 밥, cháo 죽, rau 채소... Mèo đặc biệt thích đồ tanh 비린 것 và mèo quen ăn nhạt... Thói quen của mèo: vờn chuột 쥐를 놀린다, nghịch trứng 달걀을 굴린다/ 어른다, liếm chân 발을 핱다, rửa mặt 세수를 하다, giấu vuốt 발톱을 감춘다, khi bắt chuột không kêu 울지않다, hay cào 할퀸다, mèo cắn 물다/ 물어 죽이다... Thói quen bài tiết: 똥을 덮다, đánh rắm 방귀를 뀐다, cứt mèo chua 구리다... Đặc điểm sinh sản: mèo không đẻ trứng 알, mèo có thể bị sẩy thai 낙태하다...

\section{2. Đặc điểm các loại mèo}

Theo Song Jae Seun (1997), có 160 đơn vị có yếu tố chỉ "mèo", còn lại là các đơn vị 
có yếu tố chỉ "mèo trộm/ mèo ăn vụng" (10 đơn vị), "mèo hiền lành" (4 đơn vị), "mèo lanh khôn" và "mèo đáng ghét" (mỗi loại 6 đơn vị), "mèo không biết bắt chuột" và "mèo mù" (mỗi loại có 5 đơn vị).

\section{1) Mèo mù 눈 먼 고양이}

Hình ảnh mèo mù xuất hiện trong tục ngữ vừa đáng thương, vừa đáng giận: Mèo mù chỉ bắt gà con (눈 먼 고양이가 병아리만 잡아먹는다), mèo mù chỉ làm việc mù dỏ (눈 먼 고양이 문 먼 짓만 한다): người mù không nhìn được nên không thể phán đoán sự tình chính xác, thường gây thiệt hại cho người khác, thậm chí là gây thiệt hại lớn: mèo mù không bắt chuột mà bắt gà mái giống (눈 먼 고양이 잡으라는 쥐는 안 잡고 씨암탉만 잡는다); nhu mèo mù lac trong bãi sậy (눈 먼 고양이 갈밭 헤 매듯 한다): cũng giống như tình cảnh éo le khi con mèo mù lạc trong bãi sậy, người mù cũng gặp nhiều khó khăn, trở ngại trong cuộc sống, sinh hoạt. Mèo mù nâng niu trứng $g \grave{a}$ (눈 먼 고양이 달걀 어르듯 한다): câu tục ngữ chỉ việc con người giữ vật ít giá trị nhưng cứ nâng niu, tiếc mà không dùng...

\section{2) Mèo trộm 도둑 고양이}

Người Việt hay dùng cụm từ mèo ăn vung, trong khi người Hàn lại chỉ thẳng hành động ăn vụng thức ăn đó là trộm cắp, và gọi tên những con mèo có tính xấu đó là mèo trộm: Mèo biết mùi thức ăn sẽ thành mèo ăn vụng ( 고양이가 반찬맛을 알면 도둑고양이가 된다), chỉ ranh giới giữa giữ mình trong sạch và sa ngã, phạm tội rất mong manh. Câu: Mèo ăn vung lên cả bàn thờ (도둑고양이가 제상에 오른다) ý nói: kẻ trộm thường rất táo tợn, bất chấp lễ nghi, phép tắc. Nhu mèo ăn vung bị đòn (도둑고양이 매 맞듯 한다) diễn tả ý: mắc lỗi thì bị phạt. Mèo ăn vụng buớng binh (도둑고양이는 코가 세다): những đứa trẻ hư hay người xấu thường khó bảo, không nghe lời. Mèo ăn vung không biết lối còn nghênh ngáo (도둑고양이 주제에 기세까지 부린다): những kẻ xấu lạc lối thường không thể tự nhận thức được lỗi lầm của mình và có thái độ không đúng mực. Tuy nhiên, những người có hành động xấu thường không tốt đẹp gì: Mèo ăn vung không béo đuooc (도둑고양이 살 안 찐다) ....

\section{3) Mèo đáng ghét 미운 고양이}

Mèo đáng ghét vì nhiều tính xấu: mèo đáng ghét chỉ bắt gà con (미운 고양이가 병아리만 잡아먹는다), mèo đáng ghét bắt gà mái giống (미운 고양이가 씨암탉 물어죽인다), mèo đáng ghét ngậm cò rủ leo lên mặt bếp (미운 고양이가 조기 물고 부뚜막에 오른다), mèo đáng ghét ia cả vào thảm chùi chân (얄미운 고양이가 아랫문 이불 속에 똥 싼다)...

4) Mèo không biết bắt chuột 쥐 못 잡는 고양이

Theo nếp nghĩ thông thường, đã là mèo thì tất nhiên phải biết bắt chuột, và còn bắt chuột giỏi. Tuy nhiên, loài mèo cũng như loài người, cũng có mèo thế này mèo thế kia: mèo không bắt được chuột chỉ biết ăn (쥐 못 잡는 고양이가 먹기는 더 먹는다): chỉ con mèo vô dụng, không được nết gì. Câu tục ngữ có mèo không bắt đuợc chuột cuung tốt (쥐 못 잡는 고양이도 있는 것이 낫다) hàm ý: mèo không bắt được chuột nhưng có tiếng mèo, chuột cũng sợ mà đi mất. Trong cuộc sống, đôi khi, chúng ta cũng nên nhìn vào khía cạnh tích cực của sự vật, hiện tượng mà đánh giá sự vật hiện tượng, hài lòng với thực tế để có cuộc sống an nhiên...

\section{5) Mèo hiền lành 얌전한 고양이}

Mèo hiền lành, mèo ngoan trong tục ngữ tiếng Hàn lại không phải là hình ảnh đẹp 
thực sự, ví dụ như: mèo ngoan ía cả vào thảm chùi chân (얌전한 고양이가 아랫문 이불 속에 똥 싼다), mèo ngoan leo lên mặt bếp ( 얌전한 고양이가 부뚜막에 오른다), mèo ngoan ngậm cờ rủ leo lên chạn bát (얌전한 고양이가 조기 물고 조왕에 오른다)... Có thể thấy, dân tộc Hàn có cái nhìn khá hài hước khi tạo nên các đơn vị tục ngữ đầy hàm ý, chơi chữ, "mèo ngoan" trong tục ngữ Hàn Quốc lại mang đầy đủ những nét xấu của mèo hư, đáng ghét; gọi là "ngoan" nhưng qua đó lại thể hiện thái độ chê cười, là mỉa mai, châm biếm...

\section{6) Mèo lanh khôn 약빠른 고양이}

Trong tục ngữ Hàn Quốc, mèo khôn lanh không nhận được nhiều sự ca tụng, tán dương. Người Hàn chú ý nhiều hơn đến những thiệt thòi, khiếm khuyết của những chú mèo lanh lợi trong nhà cũng như những người có tài trong xã hội. Câu tục ngữ mèo khôn không nhin rõ đêm tối (영리한 고양이가 밤눈이 어둡다), mèo khôn không thấy đằng truớc ( 약빠른 고양이가 앞을 못 본다) ám chỉ con người ta ai cũng có điểm yếu. Câu tục ngữ mèo khôn cũng có lúc không bắt được chuột (약빠른 고양이가 쥐 놓칠 때가 있다) nhấn mạnh hiện tượng thường xảy ra trong cuộc sống: người tài cũng có khi mắc lỗi, có lúc thất bại. Câu mèo khôn không được khen thuoóng (약빠른 고양이가 상 못 탄다) chỉ việc người làm nhiều thường chịu thiệt. Câu mèo khôn không có đôi (약빠른 고양이가 짝을 못 얻는다) lại mang nghĩa người sắc sảo thường kén chọn, khó kết hôn, phải sống cô độc...

Có thể thấy, hình ảnh con mèo trong mắt người Hàn là hơi tiêu cực, vì thế họ có cái nhìn mỉa mai ngay cả khi họ gọi chúng là mèo hiền lành, mèo lanh lợi, tinh khôn. Điều này có thể coi là một điểm khác biệt khi liên hệ với tục ngữ Việt có yếu tố chỉ mèo. Trong tiếng Việt, ngoài các tên gọi: mèo lười, mèo ăn vụng, mèo mù... chúng tôi không thấy xuất hiện các đơn vị tục ngữ tương ứng có tên mèo hiền lành, mèo lanh khôn... Trong thực tế cuộc sống, việc có một con vật nuôi trong gia đình cũng gây nhiều phiền toái đối với con người, dù đó là một vật nuôi có ích như mèo. Phải chăng là đối với vật nuôi trong nhà, người Hàn có thái độ khắt khe hơn so với người Việt?

\section{Giá trị biểu trưng của tục ngữ tiếng Hàn có yếu tố chỉ con mèo}

2.1. Giá trị giáo huấn, truyền kinh nghiệm, cảnh báo

\subsubsection{Giá trị giáo huấn}

Tấm lòng độ lượng của người trên đối với người dưới, có thể bỏ qua những việc không vui, không hài lòng... được dân tộc Hàn đề cao như: Mèo thwơng cho hoàn cảnh của chuột ( 고양이가 쥐 사정 봐주듯 한다). Ngoài ra, trong tục ngữ tiếng Hàn có yếu tố chỉ con mèo cũng hàm chứa nhiều bài học, lời giáo huấn có giá trị. Con người sống trên cuộc đời này cần có bản lĩnh, tự tin mới làm được việc: mèo nhát không thể bắt chuột (겁 많은 고양이는 쥐를 못 잡는다). Ai cũng có khả năng tiềm ẩn, chỉ là tạm thời chưa có cơ hội thể hiện mà thôi, khi cờ đến tay ai người đó phất, nhất định họ sẽ thể hiện bản thân một cách tốt nhất mà chúng ta không ngờ. Câu tục ngữ nếu không có mèo thì chuọt nhảy nhót (고양이가 없으면 생쥐가 날뛴다) ý nói: không có người lớn thì người nhỏ làm thay việc của người lớn. Người Việt có câu tục ngữ với ý nghĩa tương ứng: con chị nó đi, con dì nó lớn. Trong tiếng Việt còn có: không có chó phải bắt mèo ăn cứt, Không trâu bắt bò đi $c a ̀ y$ với ý nghĩa tương tự nhưng sắc thái ít 
nhiều mang tính tiêu cực hơn. Trong tiếng Anh có đơn vị tục ngữ sử dụng hình ảnh tương đồng với tục ngữ tiếng Hàn: When the cat is away, the mice will play (Vằng mèo, chuột nhảy múa) nhưng lại chuyển tải một thông điệp khác: không có chủ ở nhà thì trẻ con nghịch ngợm, phá phách giống như nhà không có mèo thì chuột làm loạn. Với ý nghĩa biểu trưng này, tiếng Việt có đơn vị tương đương là: Vắng chúa nhà, gà vọc niêu tôm... Bên cạnh đó, người Hàn cũng khuyên: trong cuộc sống, luôn phải chuẩn bị, phải xây dựng nền tảng, cơ sở cho sự nghiệp tương lai, cần có tầm nhìn xa rộng để phấn đấu: mèo phải có trán mới đội được khăn xếp (고양이가 이마가 있어야 망건도 쓰지): nếu không chuẩn bị các điều kiện cần và đủ thì việc không thể thành cũng như trán mèo hẹp không đội được khăn, ta sẽ không thể nắm bắt và tận dụng thời cơ khi có cơ hội. Câu mèo có mặt mói đánh rắm (고양이도 낯짝이 있어야 방귀 뀐다) lại có ý nghĩa: người phải làm đúng việc của mình mới có thể giành được quyền lực...

Quan niệm về giá trị của dân tộc Hàn cũng gần gũi với người Việt: coi trọng nội dung hơn hình thức, coi trọng đạo đức hơn tài năng hay vẻ đẹp hình thức: mèo thì cần bắt chuột giỏi hơn là đẹp (고양이는 꼴보다 쥐를 잘 잡아야 한다). Tuy không có đơn vị tục ngữ có yếu tố chỉ mèo với nghĩa tương ứng, nhưng người Việt có câu: tốt gỗ hơn tốt nước sơn, cái nết đánh chết cái đẹp... Con người sống phải có trách nhiệm với công việc của mình, cũng giống như hành động của con mèo khi đại tiện, tiểu tiện: mèo giáu cút (고양이도 제 똥은 덮는다)... Trong thành ngữ Việt có hình ảnh tương tự: Nhu mèo giấu cưt. Tuy nhiên, hình ảnh này lại hàm chứa ý phê phán sự cẩu thả, thiếu cẩn thận, qua quít, sơ sài của con người khi làm việc hoặc thái độ giấu giếm không cần thiết khi mọi việc đã quá rõ ràng, ai cũng biết...

Trong một tập thể, một xã hội, mỗi người có một thế mạnh và sở trường riêng. Người lãnh đạo cần biết rõ và ý thức được điều này để dùng người cho hiệu quả, phát huy được thế mạnh của mỗi người, đóng góp vào sự nghiệp chung: việc bắt chuột thì ngựa thiên li không bằng mèo (쥐 잡는 데는 천리마가 고양이만 못 한다). Tục ngữ Việt có câu: Chó giũ nhà, mèo bắt chuột: ý nói ai cũng có nghề nghiệp chuyên môn của mình, đừng tị nạnh và cũng đừng can thiệp vào việc của nhau.

Con người sống cần có hiểu biết về thế giới và sự vật hiện tượng xung quanh: ria mèo trắng tù khi lọt lòng (고양이는 날 적부터 수염이 희다): râu trắng như cước của mèo là bẩm sinh. Chỉ cho những người trẻ nhưng để râu, hoặc có râu trắng lại tưởng mình đã rất trưởng thành, việc bắt chước hoặc có cách hành xử như của người lớn tuổi hay các bậc hiền giả, đức cao vọng trọng là không phù hợp, dễ trở thành kệch cỡm... Hình ảnh mèo sinh ra đã cào (고양이새끼는 나면서 할퀸다) hay không có mèo con không biết cào (할퀴지 않는 고양이새끼 없다); tương tự, ta có: không có mèo chê đồ tanh (비린 것 안 먹는 고양이 없다): hành động "cào" hay thích ăn đồ tanh của mèo mang tính bản năng, di truyền. Việc nhận thức được bản chất và qui luật vận động, phát triển của sự vật hiện tượng sẽ giúp con người hòa nhập với thiên nhiên, khai thác được ưu đãi của thiên nhiên, phục vụ đời sống tinh thần và vật chất của mình.

Thế giới con người phức tạp và nhiều cạm bẫy, rủi ro: có mèo có hổ (고양이도 있고 범도 있다): xã hội có người nọ người kia, có người xấu người tốt, có người giàu người 
nghèo, có người sang người hèn ... rất đa dạng. Vì thế, để tồn tại và phát triển, cần trân trọng và giữ kín bảo bối, vũ khí của mình: $n h u$ mèo giấu vuốt (고양이는 발톱을 감춘다): mèo thường giấu kín vuốt sắc nhọn, chỉ dùng khi bắt chuột. Bên cạnh đó, trong hành động, ứng xử, cần phải linh hoạt: nhìn mèo vẽ hổ ( 고양이 보고 범을 그린다): không có hình mẫu thật thì có thể dùng hình mẫu tương tự. Sự thống nhất trong một tập thể, một nhóm người bao giờ cũng tạo nên sức mạnh. Một nước không có hai vua, nếu không sẽ loạn vì tranh giành quyền lợi: một chùa nhỏ hai mèo (작은 절에 고양이가 두 마리다) thì nhất định chùa không yên...

Về kinh nghiệm đối nhân, xử thế, người Hàn truyền bài học cho con cháu: chuột bị dồn đường cùng cũng quay lại cắn mèo (쥐도 막다른 골목에서는 고양이에게 덤빈다). Trong khi người Việt dùng hình ảnh: chó cùng cắn giậu: khuyên con người không nên dồn con người ta vào đường cùng, bởi con giun xéo mãi cũng quằn, dù hận thù thế nào cũng để cho con người ta con đường sống...

Trong tiếng Việt có khá nhiều đơn vị tục ngữ có yếu tố chỉ con mèo mang giá trị giáo huấn. Trong làm ăn, kinh doanh không nên quá ảo tưởng mà nóng vội, làm những việc vượt khả năng của mình: phải làm từ những việc nhỏ, phù hợp: Mèo nhỏ bắt chuột con. Sống lâu, từng trải và chiêm nghiệm cuộc sống sẽ giúp con người dần trở nên sáng suốt, khôn khéo, và đó chính là bí quyết thắng lợi: Mèo già hoá cáo. Muốn phân định, đánh giá cao thấp, hon thua, thì phải chờxem thưc tế, khi đó mói có thể biết: Chẳng biết mèo nào cắn mỉu nào: Mỗi người đều có sở trường riêng của người ấy, chưa chắc ai đã hơn ai. Muốn thành công, phải kiên trì, nhẫn nại: Nhu mèo rình chuột: kiên nhẫn, siêng năng cho đến khi được việc mới thôi.

\subsubsection{Giá trị truyền kinh nghiệm}

Con người cần giác ngộ và chấp nhận sự thật là: năng lực nhận thức, cảm nhận thế giới của mỗi cá nhân trong xã hội sẽ khác nhau tùy thuộc vào đặc điểm của đối tượng nhận thức và đặc điểm của chủ thể nhận thức: Khó phân biệt sự vật không có ranh giới rõ ràng: $n h u$ mèo đen nhắm mắt (검은 고양이 눈 감은 격이다): khi mèo đen nhắm mắt, khuôn mặt mèo sẽ hòa làm một, tất cả đều là màu đen, ta sẽ không thể nhận ra được vị trí của mắt mèo. Khi tuổi cao, mọi năng lực của con người đều giảm sút do cơ thể sinh học trở nên tàn tạ, suy thoái: mèo già đánh hoi thịt (고기 냄새 맡은 늙은 고양이다): Không chuẩn vì già nên không còn tinh nhạy nữa. Người Việt có câu: Mèo già thua gan chuột nhắt: mèo già không những yếu sức mà còn nhát gan, vì sức yếu nên biết lượng sức mình...

Qua tục ngữ, người Hàn truyền lại cho đời sau về bí quyết thành công: Kín đáo, bí mật, thận trọng khi hành động: mèo bắt chuột không tiếng động (고양이는 소리 없이 쥐를 잡는다), mèo khi bắt chuột không kêu (고양이도 쥐 잡을 때는 울지 않는다). Thậm chí, nếu cần, có thể bôi mõ vào gan bàn chân mèo (고양이 발바닥에 기름 발랐다): nhẹ nhàng không một tiếng động (để không ai biết). Câu tục ngữ: mèo to mồm không bắt đươc chuọt (우는 고양이는 쥐를 못 잡는다): ý nói những người khoa trương, to mồm thường không thành công...

Kinh nghiệm của dân gian khi thực hiện công việc, có những việc đơn giản, trong tầm tay: dễ nhu chuột bắt mèo (고양이 쥐 잡듯 한다). Nhưng, ở vào thời điểm không thích hợp thì công việc dễ dàng đó hóa ra lại khó có thể thực hiện được: mèo no bụng không thể bắt chuột (고양이도 배가 부르면 쥐를 잡지 
못한다). Trước khi hành động, cần quan sát, phân tích để tìm ra nguyên nhân vấn đề, như vậy, mới có thể giải quyết tận gốc và triệt để và hiệu quả: đừng đuổi mèo, cất thịt cá đi là duooc (고양이 쫓지 말고 고기를 치우랬다): không cần đao to, búa lớn; chỉ cần tìm ra và giải quyết đúng nguyên nhân sự việc là xong. Bên cạnh đó, chúng ta nên có thái độ dứt khoát, vứt bỏ, đoạn tuyệt đối với những đồ vô dụng, không cần thiết: nhu mèo bỏ vỏ cua... ( 고양이 게껍질 버리듯 한다)...

Về kinh nghiệm thời tiết, chúng tôi chỉ thu thập được một đơn vị tục ngữ tiếng Hàn có nội dung liên quan: mèo rưa mặt thì trời mura (고양이가 세수를 하면 비가 온다). Trong tục ngữ Việt, các đơn vị có giá trị truyền kinh nghiệm về thời tiết khá phong phú nhưng chúng tôi không phát hiện đơn vị tục ngữ nào có yếu tố chỉ mèo mang ý nghĩa tương tự.

\subsubsection{Giá trị cảnh báo}

Qua tục ngữ, dân tộc Hàn cảnh báo cho người đời sau về những nguy cơ, những hậu quả xấu có thể xảy ra trong cuộc sống. Trong cuộc sống, chúng ta không nên có những hành động thiếu sáng suốt, không khôn ngoan, bởi chúng sẽ gây hậu quả nghiêm trọng. Kiểu như các việc làm dại dột sau: nhu giao cho mèo cái đầu bò (고양이가 쇠대가리 맡은 격이다), hay nhu sai mèo làm chân coi kho thit (고양이를 육고직이 시킨 격이다), hoặc là: nhu (để) thịt cá truớc mặt mèo (고양이 앞에 고기 반찬이다), nhu giao cá cho mèo (고양이에게 생선 맡긴 격이다) ... Tương ứng với các cách biểu đạt đa dạng như vậy, người Việt hay dùng hình ảnh: mõ để miệng mèo. Bên cạnh đó, để thể hiện tinh thần cảnh giác đề phòng, biện pháp đối phó với các thủ đoạn trộm cắp, ăn vụng của vật nuôi trong nhà, ông cha ta cũng căn dặn: Chó treo, mèo đậy...
Tục ngữ Hàn có yếu tố chỉ con mèo hàm chứa ý nghĩa cảnh báo hậu quả xấu: giết mèo thì vận đen sẽ tới (고양이를 죽이면 액운이 들어온다): mèo là con vật có ích, vì thế, nếu giết mèo, ta đã làm một việc xấu và sẽ chịu quả báo. Các câu tục ngữ cảnh báo tình thế nguy hiểm: nhu chuột gặp mèo (고양이 만난 쥐다), nhu chuột bị mèo đuổi (고양이에 게 쫓기는 쥐다). Người Việt dùng hình ảnh: Chuột gặm chân mèo: Làm một việc liều lĩnh, nguy hiểm. Ngoài ra, trong tục ngữ Hàn, con mèo tượng trưng cho sức mạnh, quyền lực, cả sự chết chóc đối với chuột: nhu nơi mèo tới là chuột chết (고양이 간 데 쥐 죽은 듯한다): ý nghĩa của câu này chỉ nơi đang ồn ào bỗng trở nên yên ắng, như lũ chuột đang làm loạn, mèo tới là yên...

Thế gian nhiều lọc lừa, xảo trá. Câu tục ngữ Hàn cảnh báo nguy cơ con người dễ bị lừa: nếu đổi mèo lấy mèo, thế nào trong hai con cũng có mèo ăn vung (고양이와 고양이를 바꾸면 그 중에 도둑 고양이가 있다). Trong thực tế, không ai đem đổi hai vật như nhau cho nhau cả bởi khi trao đổi, người nào cũng có tính toán thiệt hơn. Nếu mang mèo đi đổi mèo, thế nào trong hai con mèo đó, cũng có một, thậm chí có thể là cả hai con đều là mèo ăn vụng, hoặc xấu nết - hay bắt gà, hoặc vô dụng - không biết bắt chuột. Khi cảnh báo cảnh giác với trộm cắp, người Hàn dùng câu: nghèo đến mức chẳng có gì nấu cháo cho mèo, vẫn có cái để trộm lấy đi (고양이 죽 쒀 줄 것은 없어도 도둑 가져갈 것은 있다). Kẻ trộm cắp, phần nhiều là do túng quẫn mà làm liều. Vì thế, ngay cả những nhà nghèo đến mức mèo còn không có cháo ăn thì kẻ trộm vẫn tìm ra cái có giá trị để lấy đi...

Đối với quan hệ giữa người trên và kẻ dưới, tục ngữ Hàn cảnh báo người người trên phải quan tâm, tôn trọng cấp dưới, người dưới, 
bởi: chuột nổi dậy thì mèo cũng thiệt thân (가 덤볐다면 고양이만 망신한다): Nếu bị áp bức và chịu nhiều bất công quá, người dưới sẽ phản kháng, chống lại người trên. Tuy là người dưới có lỗi (vì vi phạm tôn ti, trật tự xã hội phong kiến), nhưng người trên cũng có phần trách nhiệm và sẽ phải gánh chịu thiệt hại về uy tín, thậm chí là những tổn hại cả về vật chất lẫn tinh thần.

Tục ngữ Việt cảnh báo nếu con người không sáng suốt, không biết tự lượng sức mình sẽ dễ thất bại bằng câu tục ngữ: Mèo con bắt chuột cống, sự chênh lệch trong tương quan lực lượng quá lớn -thể hiện qua hình ảnh mèo con (nhỏ bé, yếu ớt, non nớt) và chuột cống (to lớn, khỏe mạnh, khôn ngoan), khả năng để bên yếu có thể lật ngược lại thế cờ khi đối đầu, đọ sức với phe mạnh là vô cùng hiếm hoi, thậm chí là không thể có, vì thế, chúng ta cần cẩn trọng, sáng suốt biết lượng sức khi hành xử.

\subsection{Giá trị lên án, đả kỉch, phê phán, châm biếm}

\subsubsection{Giá trị lên án, đả kích}

Tục ngữ là vũ khí đấu tranh của người dân bị áp bức trong xã hội phong kiến. Người xưa bất bình và lên án những bất công trong xã hội, người làm nhưng người khác hưởng: chó bắt chuột nhưng mèo ăn chuôt (개가 쥐를 잡고 먹기는 고양이가 먹는다). Người làm nhưng không được ghi nhận công sức, không được đãi ngộ xứng đáng: không biết đức của mèo và con dâu ( 고양이 덕과 며느리 덕은 모른다), không biết đúc của mèo và bố (고양이 덕과 아비 덕은 모른다)... Có thể thấy, trong tục ngữ có yếu tố chỉ mèo, người Hàn xưa đánh giá cao vai trò của người con dâu ngang với vai trò của người bố trong gia đình. Hiện tượng khá đặc biệt này có thể lí giải vì tục ngữ là kết quả đúc kết kinh nghiệm, tư tưởng từ ngàn xưa của dân tộc Hàn, trong khi tư tưởng trọng nam khinh nữ là kết quả của Nho giáo thời Choson.

Thói giả dối, thâm hiểm của con người cũng là đối tượng bị người dân lên án, đả kích: nhu mèo nghĩ về chuột (고양이가 쥐 생각하듯 한다): chỉ trích đó là suy nghĩ xấu xa, định hại người chứ không phải có ý tốt; $n h u$ mèo ăn rau (고양이 채소먹기다): kẻ giả nhân giả nghĩa, không ăn thịt nhưng trong lòng thâm độc; đầy dã tâm nhưng bề ngoài tỏ ra tử tế, giả vờ trong sạch. Những kẻ lừa người bằng thủ đoạn bị vạch trần: che miệng bắt chước tiếng mèo kêu (입 가리고 고양이 흉내낸다)....

Tục ngữ thể hiện thái độ đả kích đối với giai cấp thống trị, trên dưới cấu kết làm việc xấu, giống như những kẻ vốn là kẻ thù của nhau lại bắt tay nhau, liên minh với nhau trong những âm mưu và hành động mờ ám: mèo và chuột ngủ chung (고양이와 쥐가 함께 잔다). Đặc biệt, truyền thống cha truyền con nối gây nhiều phiền toái và nỗi khổ cho người dân. Tục ngữ phê phán thói hung hăng, cậy thế của con cháu tầng lớp quí tộc phong kiến không có con cháu quí tộc không hung hăng, không có mèo con nào không biết cào (앙칼없는 양반새끼 없고 할퀴잖는 고양이새끼 없다). Tất cả chúng đều xấu xa như vậy, dù được ăn học đàng hoàng, bởi trong thực tế, giai cấp thống trị như cha mẹ của dân, có quyền lực tuyệt đối, không ai dám phản khảng. Trong tục ngữ có yếu tố chỉ con mèo, người Việt lên án hạng người lăng nhăng, sống đầu đường, xó chợ, ăn chơi đàng điếm, không có nhân cách, đáng

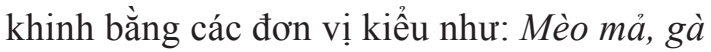
đồng, Mèo đàng chó điếm.... 


\subsubsection{Giá trị phê phán}

Thấp hơn một cấp độ khi so với lên án và đả kích, giá trị phê phán trong tục ngữ thường hướng tới những thói hư, tật xấu của tầng lớp trung gian hoặc dân thường. Đó chính là thói keo kiệt, bủn xỉn có ảnh hưởng không tốt, thậm chí gây hại với người khác: phú nông $n u o ̂ i ~ m e ̀ o ~ g \hat{\hat{a} y}$ (부자 농부가 마른 고양이 기른다): giàu nhưng keo kiệt, bỏ đói cả vật nuôi - dù mèo là con vật có ích; keo kiệt đến mức: cơm nguội cho mèo ăn cũng tiếc ( 쉰밥도 고양이 주기는 아깝다) ...

Qua tục ngữ, người Hàn và người Việt phê phán mối quan hệ không tốt, hay mâu thuẫn giữa những người chung cảnh ngộ với nhau với cùng một hình ảnh: nhux chó vói mèo (고양이와 개 사이다). Phê phán gay gắt những người vô ý thức: mèo biết là đồ ăn của su u? (고양이가 원님의 반찬을 안다더냐?). Thái độ đối nhân xử thế thiếu tôn trọng, hay giễu cợt, mỉa mai người yếu thế cũng được nhắc tới: nhu mèo vờn chuột (고양이가 쥐 놀리듯 한다). Phê phán những người có thái độ kích động, chửi người thậm tệ, ác khẩu, người Hàn có câu: nhu chưi mèo ăn vụng (반찬 먹는 고양이 잡도리하듯 한다).... Khi phê phán người đời giả dối, không tốt, người Hàn dùng hình ảnh: nhu chuột khóc $m e ̀$ (고양이 죽은 데 쥐 눈물 흘리듯 한다), nhu chuột buồn bã truớc cái chết của mèo ( 고양이 죽은 데 쥐 서러워하듯 한다)... Mèo là kẻ thù truyền kiếp, là nỗi sợ hãi của chuột, vì thế, nếu mèo chết, tất nhiên là chuột phải mừng vui. Vì thế, sẽ không có chuyện chuột khóc mèo. Thói láo hỗn, hung hăng bị con người chỉ trích: mèo có thói láo hồn (고양이 버릇이 괘심하다); mèo con ghê ghóm, hung hăng ( 앙칼맞기는 고양이새끼); phê phán người chỉ biết lợi cho mình: mèo khôn lỏi (씨바른 고양이다)...
Khi phê phán cách làm việc qua quít, đại khái, không chuẩn theo yêu cầu, người Hàn và Việt đều dùng hình ảnh: nhu mèo rủa mặt (고양이 세수하듯 한다). Với hành động phá hoại, làm rối loạn, tan hoang, người Hàn dùng hình ảnh: nhur mèo vào tủ tường (고양이 벽장에 든 것 같다), hay: nhu mèo vào nhà kho (광에 든 고양이다). Người Việt dùng hình 「nh: Ăn nhu rồng cuốn, uống nhu rồng leo, làm như mèo mửa để phê phán cách làm việc vô trách nhiệm, không có hiệu quả, thậm chí là còn khiến người khác phải tốn sức giải quyết hậu quả mình gây ra...

Vốn là một dân tộc trọng nghĩa tình, người Hàn phê phán thái độ vô ơn, thậm chí lấy oán trả ơn của người đời: nuôi mèo con, mèo trả oán (고양이새끼 길러 놓으면 앙갚음 한다). Câu này cũng cho thấy mèo là động vật lạnh lùng, tàn ác. Phê phán người có hành động thiểu hiểu biết, sáng suốt, lại lười biếng, tục ngữ Hàn có câu: giao cửa hàng ăn cho mèo rồi ngủ cả ngày (고양이에 게 반찬 가게를 맡기고 낮잠을 잔다). Với thói huênh hoang, ngu dốt còn giả vờ hiểu biết, người Hàn dùng hình ảnh: mèo chết nhìn mèo sống kêu "meo" (죽은 고양이가 산 고양이 보고 아웅 한다). Người Việt dùng hình ảnh tương tự: Thằng chết cãi thằng khiêng.

Ngoài ra, trong tiếng Việt có nhiều đơn vị mang đậm giá trị phê phán, ví dụ như: Chó chê mèo lắm lông: Phê phán người chỉ quen chỉ trích, phê phán người trong khi bản thân mình cũng vậy hoặc còn tệ hơn thế. Phê phán những người giận dữ mà không dám nói thẳng, trút giận lên người khác hoặc chửi bóng gió, xa xôi, ông cha ta dùng hình ảnh: Mắng chó chưi mèo, Đá mèo, quèo chó; phê phán thói giả dối bằng câu: mèo già khóc chuột; phê phán thói hà tiện với Buộc cổ mèo, treo cổ chó: nói kẻ hà tiện, có tính bủn xỉn. Câu tục ngữ: Im ỉm nhu mèo ăn vung ám chỉ những kẻ cố tình che giấu tội lỗi 
bằng cách im lặng tuyệt đối, hoặc những kẻ hễ thấy lợi là giấu giếm hưởng một mình, không cho ai hay biết. Câu Không có chó bắt mèo ăn cưt khuyên ta không nên hồ đồ, miễn cưỡng dùng một người trong một việc không đúng với sở trường, khả năng của người đó....

\subsubsection{Giá trị châm biếm, trào phúng}

Tục ngữ Hàn thể hiện thái độ châm biếm đối với những người hay cảnh giác, có thái độ đề phòng thái quá: nhu mèo thấy chó ( 고양이가 개 보듯 한다); chế giễu người hay run sợ: (như) chuột truoóc mèo (고양이 앞에 쥐다), (như) buớc chân chuột truớc mèo ( 고양이 앞에 쥐걸음이다); cười chê người lớn tiếng kêu gào vì đau: (như) mèo kêu đau dái (고양이 불알 않는 소리를 한다)... Câu tục ngữ mèo cuời đứt ria (고양이가 웃다가 수염 부러지겠다) chỉ câu chuyện nực cười, bất ngờ. Khi châm biếm người chỉ lo những chuyện không đâu vào đâu, hoang đường, không thể thực hiện được, hai dân tộc có chung một liên tưởng: lo đeo chuông cổ mèo ( 고양이 목에 방울 달 궁리다) ...

Khi chê người không chú tâm vào công việc, uể oải, đù đờ, vô dụng, tục ngữ Hàn có câu: nhu mèo murọn (빌려온 도양이 같다). Người Việt cũng có lối tư duy tương tự khi muốn nói người mình mệt mỏi: nguoòi nhu đi mươn. Chế giễu những người viết chữ xấu, nguệch ngoạc, người Hàn ví von: vẽ chân mèo chân chó ( 고양이 발 개 발을 그린다) còn người Việt nói: chữ $n h u ̛$ gà bới. Khi chê cười người làm việc không nhanh, sờ sẩm, chậm chạp người Hàn nhiếc: nhu mèo mù tìm hang chuột lúc trời tối (밤눈 어둔 고양이가 쥐 구멍 더듬듯 한다), người Việt nói: nhu sẩm sò̀...

Chuyện ăn uống, nói năng cũng thu hút sự chú ý của người dân: Người Hàn chê người ăn ít: nhu mèo ăn com/ ăn nhu mèo (고양이
밥 먹듯 한다). Người Việt cũng dùng hình ảnh: ăn như mèo, mèo uống nước bể chẳng bao giờ cạn... Người hay nói nhiều, nói điêu, nói dối bị giễu là tiếng mèo/ giong mèo (고양이 소리다)... Chuyện ăn mặc, hình thức cũng trở thành đối tượng châm biếm: Chê cười người ăn mặc lố lăng, kệch cỡm người Hàn ví: nhu mèo măc đồ thêu diêm dúa (고양이 수파 쓴 것 같다). Chê người ở bẩn, mặt mũi lem nhem, người Việt chê: nhu mèo rưa mặt; người Hàn ví nhu tay mèo bốc cháo bí ngô (범벅 먹은 고양이 손 같다), hay: nhu măt mèo vìa ăn chuôt (쥐 잡아먹은 고양이 상이다) ...

Câu tục ngữ hẹp nhu trán mèo (고양이 이마처럼 좁다) hàm chứa 2 ý nghĩa: 1) cười người có trán hẹp; 2) chế người có tầm nhìn, ý kiến hẹp hòi. Khi giễu người có vẻ mặt nhăn nhó, tục ngữ Hàn có cách biểu đạt khá đa dạng: nhu mặt mèo hít phải khói độc (내 마신 고양이 상이다, mặt mèo bị sẩy thai ( 고양이 낙태한 상이다); mặt người ốm, nhăn nhó vì đau khổ được ví như: nhu mặt mèo hút thuốc lá (상판때기가 담뱃진 먹은 고양이 상이다), nhu mặt mèo ăn muối (소금 먹은 고양이 상이다), $n h u$ măt mèo bi trĩ (치질 앓는 고양이 상이다) ...

Ngoài ra, người Việt cười châm biếm cho trường hợp gặp may bất ngờ đạt được cái hoàn toàn ngoài khả năng của mình: Mèo mù vớ cá rán... Chúng tôi không phát hiện biểu đạt tương ứng trong tục ngữ Hàn.

\section{Dấu ấn văn hóa của dân tộc Hàn}

3.1. Đời sống vật chất và tinh thần của dân tộc Hàn

3.1.1. Phản ánh đời sống vật chất, môi trường sống

Tục ngữ phản ảnh đời sống, môi trường sống của các dân tộc sử dụng ngôn ngữ đó. 
Người Hàn coi trọng gia đình: ) đêm đến mèo cũng về nhà mình cuñng nhu con người tố $i$ trở về nhà nghi ngơi (밤이 되면 고야이도 제 집으로 돌아간다). Người già thường muốn cuộc sống yên bình, an toàn: mèo già tìm bậc thềm thấp (늙은 고양이가 아랫목 찾는다).... Qua tục ngữ, có thể thấy đời sống khó khăn, nghèo khổ, thiếu thốn đến mức đói khát của người dân nghèo: không có cái quấy cháo cho mèo, không có lấy một miếng cho chuọt (고양이 죽 쑤어줄 것 없고, 생쥐 볼가심할 것 없다)... Người Việt cũng có câu: Mèo mù móc cống: chỉ những kẻ tật nguyền, đói khổ, không còn phương kế sinh nhai. Câu Ăn nhạt mới biết thương tới mèo: ngụ ý con người ta có lâm cảnh khổ thì mới biết thương người không may mắn bằng mình. Người Việt quan niệm: $\breve{\text { An }}$ nhỏ nhẹ $n h u$ mèo: là ăn từ tốn, từng miếng một. Phụ nữ ăn nhỏ nhẹ được khen là có nết. Nhưng đàn ông ăn như mèo thì bị coi người thiếu sinh khí, sức mạnh. Vì thế, người Việt quan niệm: Nam thực như hổ, nũ thưc nhu miêu/ miu... mới đúng lễ nghi, phép tắc.

Cuộc sống no đủ của người dân cũng được phản ảnh trong tục ngũ ở khía cạnh khá thú vị: mèo no bụng chơi với chuột ( 고양이도 배가 부르면 쥐와 함께 논다): Con người sống đầy đủ, sung túc sẽ không làm điều xấu, không tàn nhẫn. Câu mèo no bụng hít hà mèo con (배 부른 고양이가 새끼 냄새 맡듯 한다) ý nói, nếu cuộc sống dư dả, dễ chịu, con người sẽ sống tình cảm hơn. Để miêu tả đời sống thuận lợi, sung túc, người Hàn dùng câu mèo vào $n h a ̀$ kho (도장에 든 고양이다): nhà kho nhiều chuột, mèo vào nhà kho sẽ được ăn no. Người Việt dùng hình ảnh: nhu chuôt sa chĩnh gạo, chuột vào bồ thóc... để biểu đạt ý nghĩa trên.
3.1.2. Phản ánh đời sống tinh thần của dân tộc Hàn

Tục ngữ tiếng Hàn có yếu tố chỉ con mèo có nhiều đơn vị miêu tả vẻ mặt biểu cảm đa dạng của con người: (Đờ đẫn) $n h u$ mặt mèo uống cam tưu (감주 먹은 고양이 상이다): mặt người buồn ngủ. Vẻ mặt trông ngây, ngốc được lột tả qua câu: nhu mèo thấy sò (고양이가 꼬막조개 보듯 한다): Mèo thấy sò nhưng không ăn được, chỉ nhìn ngó nên trông ngố. Vẻ mặt bất an, lo lắng: mặt mèo ăn vung sikhye (식혜 먹은 고양이 상이다): có tật giật mình, làm việc xấu bao giờ cũng lo lắng sợ bị lộ... Người Việt dùng hình ảnh: Tiu nghỉu nhu mèo cắt tai: vì thất vọng nên buồn rầu, không muốn nói năng, không muốn làm gì. Khi buồn hoặc bị mắng, mèo thường cụp tai lại trông rất đáng thương...

Các trạng thái tinh thần, tâm lí cũng được thể hiện phong phú trong tục ngữ: Nỗi sợ hãi bởi kí ức kinh hoàng: mèo bị bỏng nước sôi thấy lưa đã khiếp (긇는 물에 덴 고양이는 불만 봐도 놀란다), mèo bi bỏng nước sôi thấy nuoóc lạnh cũng hãi (끓는 물에 덴 고양이는 찬물도 겁을 먹는다); tâm trạng thất vọng, bất lực: nhu chó đuổi mèo (고양이 쫓던 개다). Câu tục ngữ chỉ biểu cảm của người thất vọng như khi con chó đuổi mèo, nhưng mèo lại leo lên mái nhà, cho ngước lên nhìn mà không làm gì được. Cảm giác thỏa mãn thể hiện qua câu: mèo nhìn chuột (쥐 본 고양이다): thỏa mãn, hài lòng vì có cái ăn. Cảm giác khó chịu, phiền muộn vì muốn ăn mà không được: $n h u$ mèo nhìn sò, ngáp (고양이 고막 보고 하품하듯 한다)... Người Hàn và người Việt có chung một cách thể hiện ngôn ngữ miêu tả sự thèm thuồng, háo hức một cách quá 
lộ liễu: nhu mèo thấy mõ (고양이가 기름 종지 노리듯 한다)... Trạng thái phấn chấn khi gặp cơ hội tốt, thuận lợi, đúng lúc: $n h u$ mèo đói thấy chuột (굶주린 고양이가 쥐를 만난 격이다). Người Việt có câu: mèo mù vớ cá rán. Ngoài ra, trong tiếng Việt còn có các đơn vị tục ngữ khác không có yếu tố chỉ mèo nhưng chuyển tải chung một ý nghĩa, ví dụ như: chết đuối vớ được cọc, buồn ngủ gặp chiếu manh...

Thể hiện thái độ phủ nhận việc hoang đường, vô lí, không có thực, không thể chấp nhận, tục ngũ̃ Hàn có các câu như: mèo sẽ đẻ trúng u (고양이 알을 낳겠다), mèo sẽ chê chuôt u. (고양이가 쥐를 마다다 하겠다), sùng mèo (고양이 뿔이다), nhu mèo ăn chay (고양이 소하는 격이다): mèo là động vật ăn thịt, không có chuyện mèo chỉ ăn rau... Người Việt nói về các chuyện hoang đường với lối hài hước hơn: Chạch đẻ ngọn đa, sáo đẻ dưới nước.... Qua tục ngữ, người Hàn cũng tỏ thái độ yêu ghét rõ ràng, dứt khoát: một cái đầu cá minh thái không phải là cái gì to tát, nhung vì mèo quá láo hỗn (nên ghét không cho)...( 명태 대가리 하나가 대단한 것이 아니라 고양이 소행이 괘씸하다) ...

\subsection{Phong tục tập quán dân tộc Hàn trong tuc ngũ chỉ mèo}

Có thể phát hiện các dấu ấn văn hóa dân tộc Hàn thể hiện qua các đơn vị tục ngữ có yếu tố chỉ con mèo như sau: Phong tục kiêng kị giống người Việt, để ý, giữ không cho mèo đến gần thi thể người đã mất: mèo nhảy qua áo quan, người chết ngồi dậy (고양이가 관을 넘어가면 송장이 일어선다); thậm chí: chi nghe tiếng mèo, thi thể cũng chuyển động ( 고양이 소리만 해도 송장이 움직이다)... Người dân đảo Cheju coi mèo là linh vật, nếu giết hại mèo, vận hạn sẽ đến: giết mèo thì vận đen sẽ tới (고양이를 죽이면 액운이 들어온다), giết mèo, mèo báo oán (고양이를 죽이면 고양이가 원수를 갚는다 ): mèo là động vật có ích, không nên giết mèo.... Dấu ấn của văn hóa nông nghiệp lúa nước, tình trạng thiếu nhân lực mỗi khi vào mùa nghiêm trọng đến nỗi phải huy động cả nhân lực yếu ớt như mèo: chắc phải muợn tay mèo (고양이 손도 빌릴 판이다), mùa gieo ma, mươn tay mèo ( 모내기 때는 고양이 손도 빌린다). Người Hàn tin vào điềm báo: âm lịch tháng giêng hai, mèo giao phối ở ruộng thì năm đó được mùa bông (정이월에 밭에서 고양이가 교미를 하면 그 해 목화가 풍년 든다), mèo liếm chân thì khách đến (고양이가 발을 핱으면 손님 온다) $\ldots$

Có thể thấy, trong các đơn vị tục ngữ Hàn và Việt có yếu tố chỉ mèo có sự xuất hiện của nhiều động vật khác, các loài xuất hiện với tần số cao là chó, chuột, gà... Điều này xuất phát từ mới quan hệ gần gũi của mèo với các loài đó: mèo - chuột: mèo bắt và àn thịt chuột, chó - mèo: hai con vật được người nuôi, một để giữ nhà, một để bắt chuột. Bên cạnh đó, mèo - gà: gà là gia cầm cũng được nuôi thả trong sân, trong vườn, vì thế, có thể nói là chúng có chung môi trường sống.

\section{Kết luận}

Bài viết đã phác họa hình ảnh con mèo trong tín ngưỡng của hai dân tộc Hàn - Việt, hình ảnh con mèo trong tục ngữ tiếng Hàn. Giá trị giáo huấn, truyền kinh nghiệm thể hiện trong tục ngữ cho thấy một phần thế giới quan, giá trị quan, nhân sinh quan của người Hàn. Con người ta sống cần độ lượng, tự tin, có bản lĩnh và biết chuẩn bị tốt để năm cơ hội; coi trọng các giá trị đạo đức, có trách nhiệm, biết phát huy sở trường, thế mạnh của mỗi cá nhân; hiểu biết về 
qui luật và bản chất của sự vật hiện tượng, xã hội loài người; cần linh hoạt nhưng cũng hết sức cẩn trọng trong ứng xử và hành động; cảnh báo nguy cơ, hậu quả xấu, thế gian lọc lừa... Tục ngữ tiếng Hàn có yếu tố chỉ con mèo cũng thể hiện thái độ phản kháng của người dân đối với những bất công, cái xấu trong xã hội; nụ cười trào phúng đối với những thói hư, tật xấu của con người. Các nét giống và khác trong văn hóa giữa hai dân tộc Hàn - Việt được khắc hoạ qua sự liên hệ ở những nét đặc trưng tương ứng. Dấu ấn văn hóa dân tộc cũng ít nhiều được thể hiện qua tục ngữ tiếng Hàn có yếu tố chỉ mèo.

\section{Tài liệu tham khảo}

\section{Tiếng Việt}

Nguyễn Thùy Dương (2013). Một số tín hiệu thẩm mỹ trong thành ngũ, tục ngũ tiếng Hàn. Luận văn Thạc sỹ chuyên ngành Châu Á học, trường ĐHKHXH \& NV- ĐHQGHN.

Nguyễn Văn Nở (2008). Biểu trung trong tục ngũ người Việt. NXB ĐHQGHN.

Vũ Ngọc Phan (2008). Tục ngũu, ca dao, dân ca Việt Nam. NXB Văn học
Trần Văn Tiếng (2006). So sánh mọt số đặc điểm cú pháp-ngũ nghĩa của tuc ngũ tiếng Việt và tiếng Hàn. luận án, ĐHQG tp.HCM

Hoàng Thị Yến, Nguyễn Thùy Dương (2016). Nghiên cứu tục ngũ tiếng Hàn có yếu tố chỉ con hổ. Tạp chí Hàn Quốc, số 01 (15), $3 / 2016$, tr. $61-76$

\section{Tiếng Hàn}

Jang Jae Hwan (2009). So sánh tục ngũ động vật Nhật - Hàn: trọng tâm là tục ngũ có yếu tố chỉ ngựa và chó. Đại học Danguk, Hàn Quốc, luận văn thạc sĩ. 장재환 (2009). 일. 한 동물 속담에 관한 비교. 고찰: '말'과 ' 개'에 관한 속담을 중심으로, 단국대학교, 석사논문.

Kim Myung Hwa (2011). Nghiên cúu so sánh tục ngũ động vật 12 con giáp Hàn - Trung. Đại học Dongjoo, Hàn Quốc, luận văn thạc sĩ. 김명화 (2011). 한-중 12 지신 동물 속담 비교 연구, 동주 대학교, 석사논문.

Song Jae Seun (1997). Tù điển tục ngũ động vật. Nxb Dongmunhak. 송재선(1997). 동물속담 사전. 東文選.

\title{
CAT-RELATED KOREAN PROVERBS
}

\author{
Hoang Thi Yen
}

\section{Faculty of Korean Language and Culture, VNU University of Languages and International Studies, Pham Van Dong, Cau Giay, Hanoi, Vietnam}

\begin{abstract}
The paper uses a combination of descriptive and comparative methods in investigating cat-related proverbs in the Korean language, explaining their meanings and classifying them into various categories in order to highlight the didactic values and lessons from life experience of the Korean people through the image of cats. Naturally endowed with various characteristics, both positive and negative, cats are used as an analogy for the Korean people to reflect their world outlook, criticism as well as protest against social evils, injustice, or their sacarsm of human undesirable personality. The national cultural footprints of the Korean people are also represented through cat-related proverbs. These form the essence of this account of cat-related Korean proverbs.
\end{abstract}

Keywords: Korean proverb, cat, symbolic value, cultural footprint 